\section{NASA budget problems alarm space-station collaborators}

\section{William Triplett, Washington}

Hopes are fading fast that money can be found in Washington to complete the construction of the International Space Station to anything approaching its original specification.

As international partners look on nervously, the national security crisis following the 11 September terrorist attacks on the United States seems to have eliminated any lingering chance that extra funds will be available to cover an estimated \$5-billion shortfall in the project's NASA budget (see Nature 412, 465-466; 2001).

Members of Congress, including influential figures such as Senator Bill Nelson (Democrat, Florida), a former astronaut, met with project supporters on Capitol Hill last week to scramble for ways to salvage the project.

"There may not be money available but there are solutions, and that's what [the meeting] was all about," says Marc Schlather, president of ProSpace, a citizens' group that helped to organize the meeting. However, few material solutions were evident during the sombre round-table discussion of station supporters.

"We are in a moment of crisis in so many ways," said Dana Rohrabacher (Republican, California). "We need to be creative in our approaches." Rohrabacher said that the governments of Italy and Ireland might be willing to contribute $\$ 1.5$ billion and $\$ 200$ million, respectively, to the project if companies in these countries were awarded contracts of corresponding value. He also suggested that NASA place equipment contracts with as many Russian companies as possible, because they have "a tremendous capability for producing hardware at cheaper prices than anywhere else".

A former congressional staff member on space issues urged NASA to consider using commercial launch services for resupplying the space station. At present it relies on the far more expensive space-shuttle flights.

Although no final decision has been made, NASA is considering changes in the station that would reduce its crew from six or seven to three. Researchers have said that such a change would effectively end the station's usefulness as a laboratory. In a preliminary copy of a report on the station's readiness, which will be formally published early next year, the National Academy of Sciences' Space Studies Board warns that "the future of science on the International Space Station would be severely impaired" by such a change.

European and Japanese space-agency

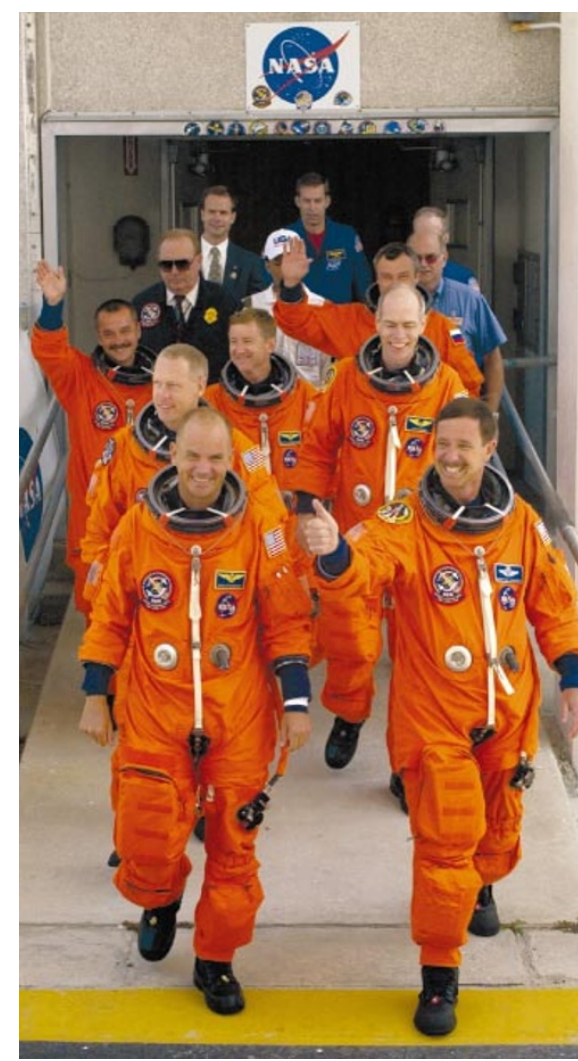

Crew cut: scientists are concerned by proposals to reduce NASA's space-station crew to just three.

officials, meanwhile, are putting a brave face on unfolding events, while researchers with projects planned grow increasingly restive. "We are looking at all possible solutions, but we are not altogether pessimistic," says Mark Heppener, head of space-station utilization at the European Space Agency.

But another European official, who declined to be identified, said: "The scientists probably have a feeling of betrayal. We have tried very hard to select the best proposals through a new system of international peer review, and now we feel that we are all on a waiting-list; we have no idea what could happen. We hope the United States will honour the international agreements it has entered into."

Yasushi Horikawa, space-station project manager at NASDA, the Japanese space agency, says: "The worst thing would be if researchers who have been preparing projects just have to keep waiting and waiting." A NASDA spokesman added that NASA's budget problems could delay the construction and launch of Japan's Kibo research module for the station, which is due in 2004 or 2005.

http://www.nap.edu

\section{Vatican approves use of animal transplants 'to benefit humans'}

Xavier Bosch

In a surprise announcement that may spur xenotransplantation research worldwide, the Pontifical Academy for Life in the Vatican has said that it does not object to the transplantation of animal organs into humans.

Although xenotransplantation may provide cells, tissues and organs to treat a variety of serious human illnesses, several groups have called for it to be banned while ethical issues and the hazards of cross-species infection are debated. In 1999, for example, the Council of Europe called for a moratorium on clinical trials involving xenotransplantation (see Nature 397, 281-282; 1999).

In a detailed report released on 26 September, the academy argues that because humans enjoy a unique and superior dignity, and God has placed nonhuman creatures at the service of people, the sacrifice of animals is justified as long as there will be a "relevant benefit for humans". Research into transgenic animals is also "morally acceptable", the report says, because of these benefits.

The report also argues that it is irrelevant, from a theological or moral viewpoint, whether primates or nonprimates, such as pigs, are used for xenotransplantation. Despite the greater immunological barrier between pigs and humans, pigs are generally favoured over primates as a source of transplant tissue for a variety of practical, ethical and safety reasons.

In a speech at the Vatican when the report was released, Marialuisa Lavitrano, a member of the Council of Europe's xenotransplantation working group, said that society should be given accurate and balanced information on the benefits and risks of xenotransplantation.

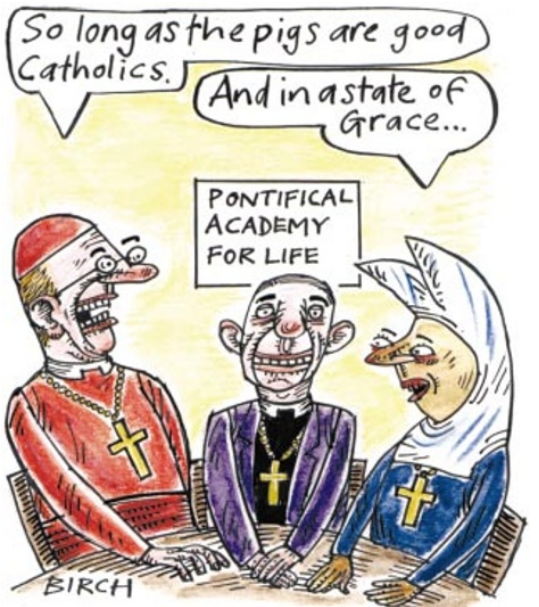

